\title{
PENGARUH PENDAPATAN DAN PERILAKU KEUANGAN TERHADAP LITERASI KEUANGAN MELALUI KEPUTUSAN BERINVESTASI SEBAGAI VARIABEL INTERVENING
}

\author{
THE EFFECT INCOME AND FINANCIAL BEHAVIOR ON FINANCIAL LITERACY \\ WITH INVESTMENT DECISIONS AS INTERVENING
}

\author{
Baiq Fitri Arianti \\ Universitas Pamulang, Jalan Surya Kencana No. 1 Pamulang Barat, Tangerang Selatan
}

\begin{abstract}
The purpose of this research to analyze the effect of income and financial behavior on financial literacy with investment decisions as an intervening variable on the SMEs of South Tangerang. The population in this study were all SMEs in the city of South Tangerang. Data collection techniques using observation, interviews, library research (Library Research), Questionnaire / Questionnaire. Then the data analysis method in this study uses path analysis with the help of the SPSS program. The results show that income has a positive and significant effect on financial literacy, financial behavior variables have a positive and significant effect on literacy, investment decisions cannot mediate income against financial literacy and investment decisions can mediate financial behavior on financial literacy.
\end{abstract}

Keywords: Financial literacy, Financial Behavior, Income, Investment Decision

\begin{abstract}
ABSTRAK
Penelitian ini dapat ditujukan untuk menganalisis dan membuktikan pengaruh pendapatan dan perilaku keuangan terhadap literasi keuangan dengan keputusan berinvestasi sebgai variabel intervening pada pelaku UMKM kota Tangerang Selatan. Populasi dalam penelitian ini adalah seluruh pelaku UMKM yang ada di kota Tangerang Selatan. Metode pengumpulan datanya dengan menggunakan observasi, wawancara, studi kepustakaan (Library Research), Kuesioner/Angket. Dan teknik analisis dalam penelitian ini menggunakan path analysis dengan bantuan program SPSS. Hasil penelitian ini menunjukkan bahwa bahwa pendapatan memiliki pengaruh terhadap literasi keuangan, variabel perilaku keuangan memiliki pengaruh terhadap literasi, keputusan berinvestasi tidak dapat memediasi pendapatan terhadap literasi keuangan dan keputusan berinvestasi dapat memediasi perilaku keuangan terhadap literasi keuangan.
\end{abstract}

Kata kunci : Literasi Keuangan, Perilaku Keuangan, Pendapatan, Keputusan Berinvestasi

Corresponding author: Baiq Fitri Arianti*

Email for author: Akt.fitri1983@gmail.com*

Submission: 06 November 2019

Revised : 02 Februari 2020

Accepted : 03 Februari 2020

DOI $\quad:$ https://doi.org/10.33369/j.akuntansi.9.3.13-36 
PENGARUH PENDAPATAN DAN PERILAKU KEUANGAN TERHADAP LITERASI KEUANGAN MELALUI KEPUTUSAN BERINVESTASI SEBAGAI VARIABEL INTERVENING

Baiq Fitri Arianti

\section{PENDAHULUAN}

Negara Indonesia merupakan Negara berkembang yang ada di kawasan Asia. Indonesia juga pernah mengalami krisis moneter yang cukup besar pada tahun 1998 dan sektor yang tetap bertahan adalah sektor Usaha Kecil Menengah (UMKM). Sebagai negara berkembang, Indonesia masih memiliki tantangan soal rendahnya literasi keuangan sehingga pemerintah memiliki peran strategis dalam meningkatkan kesejahteraan masyarakat dan meningkatkan pertumbuhan ekonomi, serta meningkatkan stabilitas keuangan nasional. Berdasarkan hasil survey OJK (2017) menunjukkan bahwa tingkat literasi keuangan Indonesia hanya 20\%. Hal ini lebih rendah dibandingkan dengan negara ASEAN seperti filipina 27\%, Malaysia 66\% Thailand 73\% dan Singapura sebesar $98 \%$. Perilaku keuangan sangat berperan dalam pengambilan keputusan investasi. Seseorang yang memiliki literasi keuangan yang bijak akan memepengaruhi perilaku keuangan yang berdampak juga pada pengambilan keputusan berinvestasi (Christanti dan Mahastanti, 2011).

Fenomena dalam penelitian ini adalah rendahnya pemahaman dan pengetahuan literasi keuangan yang terjadi pada para pelaku UMKM di kota Tangerang Selatan, hal ini dapat dilihat dari hasil wawancara terbuka dengan salah satu pegawai pemerintah kota tangerang selatan mengatakan bahwa masih belum mengetahui akan pentingnya literasi keuangan dalam mengelola keuangan dengan baik karena kurangnya pemanfaatan akses produk dan jasa lembaga keuangan terhadap sektor tersebut dan mengharapkan pelaku UMKM mendapatkan penguatan kelembagaan usaha melalui pengetahuan pengelolaan keuangan dan pembukuan usaha secara sederhana. Pemerintah kota Tangerang Selatan juga harus memberikan kesempatan kepada pelaku UMKM untuk dapat mengetahui lebih jauh produk dan layanan jasa keuangan dalam melakukan inovasi pengembangan suatu produk. Fenomena ini juga didukung dari data dinas koperasi dan UMKM (2018) tentang perkembangan UMKM kota Tangerang Selatan tahun 2015 - 2017 pada tabel 1 di bawah ini:

Tabel 1. Data Perkembangan UMKM Kota Tangerang Selatan

\begin{tabular}{lccc}
\hline Kecamatan & \multicolumn{3}{c}{ Tahun } \\
\cline { 2 - 4 } & 2015 & 2016 & 2017 \\
\hline Ciputat Timur & 3.130 & 3.910 & 3.250 \\
\hline Ciputat & 4.050 & 4.165 & 3.961 \\
\hline Pamulang & 2.731 & 2.859 & 2.215 \\
\hline Pondok Aren & 4.983 & 5.021 & 4.489 \\
\hline Setu & 1.092 & 1.662 & 1.610 \\
\hline Serpong & 3.310 & 3.558 & 3.245 \\
\hline Serpong Utara & 4.726 & 4.825 & 4.230 \\
\hline Jumlah & 24.022 & 26.000 & 23.000 \\
\hline
\end{tabular}

Berdasarkan tabel 1 diatas bahwa perkembangan pelaku UMKM di kota Tangerang Selatan yang berjumlah tujuh kecamatan mengalami penurunan sangat signifikan di tahun 2017 sebanyak 23.000 pelaku UMKM dengan tingkat persentase $11 \%$ karena dari pihak dinas koperasi dan UMKM kota Tangerang selatan sendiri belum menerapkan program edukasi literasi keuangan, disamping itu juga minimnya akses produk dan jasa keuangan terhadap sektor tersebut. Pemerintah kota Tangerang Selatan memberikan kesempatan kepada pelaku UMKM untuk memahami lebih jauh produk dan layanan jasa keuangan yang di tawarkan oleh lembaga jasa keuangan sehingga 
para pelaku UMKM mendapatkan penguatan infrastruktur literasi keuangan dan dapat melakukan inovasi pengembangan suatu produk.

Kasus yang sering terjadi di masyarakat bahwa banyaknya kasus penipuan yang berkedok investasi bodong. Dan biasaya kasus tersebut menimpa berbagai kalangan masyarakat baik kalangan yang berduit, terpelajar sampai dengan kalangan bawah yang miskin dan tidak terpelajar. Modus yang dilakukan pada kejahatan keuangan ini pasti bermula dari janji imbal hasil investasi dan bisnis yang menggiurkan sampai dengan ketidakjelasan informasi. Kejadian serupa juga menimpa masyarakat manakala berada pada pihak debitur. Masyarakat juga menegeluhkan perhitungan Bungan dan biaya yang dibebankan tidak transfaran tanpa persetujuan debitur dan berbagai kasus yang merugikan masyarakat sangat sering terjadi (Widowati dan Winarto, 2017)

Permasalahan dalam penelitian ini juga diungkapkan oleh penelitian yang dilakukan Xu dan Zia (2012) menunjukan bahwa faktor demografi, ekonomi, social dan faktor phsikologis merupakan faktor utama financial literacy yang berhubungan dengan keputusan pelaku usaha untuk berinvestasi menemukan bahwa di negara maju, literasi keuangan berkorelasi positif terhadap pengambilan keputusan berinvestasi. Selanjutnya hasil penelitian yang dilakukan oleh Anggraeni (2016) menunujukkan bahwa literasi keuangan dari pemilik usaha rendah sehingga berpengaruh terhadap kemampuan mengelola keuangan karena pemilik usaha sejauh ini belum belum memiliki kemampuan literasi keuangan yang baik sehingga pelaku usaha tersebut belum sampai untuk tahap investasi pada produk keuangan. Dan penelitian ini juga diungkapkan oleh Dea (2017) dengan judul Pengaruh Literasi Keuangan, Tingkat Pendapatan, Dan Pendidikan Terhadap Keputusan Investasi menunjukkan bahwa literasi keuangan berpengaruh positif signifikan terhadap keputusan investasi. Sedangkan, variabel tingkat Pendapatan dan pendidikan tidak ada perbedaan dalam pengambilan keputusan investasi dan penelitian ini juga sesuai dengan penelitian Arianti (2018) menunjukkan bahwa secara bersama - sama variabel literasi keuangan, pendapatan dan perilaku keuangan berpengaruh signifikan terhadap keputusan investasi.

Berdasarkan latar belakang diatas, maka penulis perlu dikaji dan teliti agar tujuan dalam pembahasannya dapat lebih terinci dan mendalam. Untuk itu penulis merumuskan beberapa hal yang akan menjadi rumusan masalah dalam penelitian ini adalah apakah pendapatan berpengaruh signifikan terhadap literasi keuangan, apakah perilaku keuangan berpengaruh signifikan terhadap literasi keuangan, apakah pendapatan berpengaruh langsung terhadap literasi keuangan melalui keputusan berinvestasi dan apakah perilaku keuangan berpengaruh terhadap literasi keuangan melalui keputusan berinvestasi.

\section{KERANGKA TEORITIS DAN HIPOTESIS}

\section{Teori Atribusi}

Atribusi teori dapat dijelaskan ketika individu mengamati perilaku individu terhadap resiko. Teori ini juga tidak jauh beda dengan teori utility, dimana dalam penelitian ini perilaku seseorang dalam melakukan pengambilan keputusan investasi dapat menghindari terjadinya resiko (Christanti dan Mahastanti, 2011). Teori ini juga relevan untuk menjelaskan perilaku keuangan seseorang dalam mengelola keuangan dengan bijak.

\section{Literasi Keuangan (Financial literacy)}

Menurut Garman dan Forgue (2000) dalam Sabri (2011) mendefinisikan melek finansial dengan tindakan mengetahui fakta-fakta dan pengertian yang diperlukan untuk mengelola keuangan pribadi sehingga berhasil mengelola keuangan dengan baik. Sedangkan menurut Kim 
(2001) dalam Sabri (2011) literasi keuangan adalah pengetahuan dasar bahwa orang perlu untuk bertahan hidup dalam masyarakat modern. Pengetahuan dasar ini melibatkan, mengetahui dan memahami prinsip-prinsip kompleks dalam melakukan pembelanjaan, menabung, dan berinvestasi.

Selanjutnya, Bhushan dan Medury (2013) mengungkapkan literasi keuangan adalah kemampuan untuk membuat penilaian informasi dan mengambil keputusan yang efektif tentang penggunaan dan pengelolaan uang. Literasi keuangan merupakan kombinasi dari kemampuan individu, pengetahuan, sikap dan akhirnya perilaku individu yang berhubungan dengan uang. Literasi keuangan juga sangat erat kaitannya dengan pengelolaan keuangan. Jika seseorang memiliki literasi keuangan yang rendah maka pengetahuan tentang keuangan sangat penting bagi seorang individu, agar tidak salah dalam membuat keputusan berinvestasi. Pengetahuan tentang keuangan yang kurang, mengakibatkan kerugian bagi individu, baik akibat dari inflasi, penurunan kondisi perekonomian baik dalam negeri maupun luar negeri, atau berkembangnya sistem perekonomian. Sesuai dengan penelitian Remund (2010) terdapat lima indikator dari literasi keuangan yaitu a) Pengetahuan tentang konsep keuangan, b) Kemampuan untuk berkomunikasi tentang konsep keuangan, c) Kemampuan untuk mengelola keuangan pribadi, d) Kemampuan dalam membuat keputusan keuangan, e) Keyakinan untuk membuat perencanaan keuangan dimasa depan.

\section{Perilaku Keuangan (Financial Behavior)}

Financial Behavior adalah suatu perilaku yang berkaitan dengan aplikasi keuangan. Menurut Ricciardi (2000) dalam Arianti (2018) mengungkapkan bahwa financial behavior adalah suatu displin ilmu yang di dalamnya melekat interaksi berbagai displin ilmu dan secara terus menerus berintegrasi sehingga pembahasannya tidak dilakukan isolasi. Perilaku keuangan (Financial Behavior) merupakan isu yang banyak dibahas saat ini. Mereka cenderung berpikir jangka pendek dan identik dengan praktik belanja impulsif sehingga seringkali individu dengan pendapatan yang cukup masih mengalami masalah finansial karena perilaku keuangan yang kurang bertanggung jawab. Financial Behavior adalah kemampuan seseorang dalam mengatur (perencanaan, penganggaran, pemeriksaan, pengelolaan, pengendalian, pencarian dan penyimpanan) dana keuangan sehari-hari. Perilaku manajemen keuangan dapat juga diartikan sebagai proses pengambilan keputusan keuangan, harmonisasi motif individu dan tujuan perusahaan. Perilaku manajemen keuangan berkaitan dengan efektivitas manajemen dana, dimana arus dana harus diarahkan sesuai dengan rencana yang telah ditetapkan. Adapun indikator dalam variabel ini, yaitu jenis-jenis perencanaan dan anggaran keuangan yang dimiliki, teknik dalam menyusun perencanaan keuangan, kegiatan menabung, kegiatan asuransi, pensiun dan pengeluaran tidak terduga, kegiatan investasi, kredit/hutang, dan tagihan, monitoring pengelolaan keuangan, dan evaluasi pengelolaan keuangan (Humaira dan Sagoro, 2018). Nababan (2012) dalam Anita Sari (2015) mengemukakan indikator financial behaviour atau perilaku keuangan adalah a) Membayar tagihan tepat waktu., b) Membuat anggaran pengeluaran dan belanja, c) Mencatat pengeluaran dan belanja (harian, bulanan, dan lain-lain), c) Menyediakan dana untuk pengeluaran tidak terduga, d) Menabung secara periodic, e) Membandingkan harga antar toko atau swalayan atau supermarket sebelum memutuskan untuk melakukan pembelian.

\section{Pendapatan (Income)}

Pendapatan merupakan jumlah besaran uang yang didapatkan seseorang atas hasil usaha dan kinerjanya. Pada dasarnya pendapatan adalah hasil atas pengorbanan seseorang alam bentuk 
materi untuk memenuhi kebutuhan hidupnya, dengan menginvestasikan sumber pendapatan yang ada, seseorang dapat memilih beragam jenis investasi secara umum seperti saham, obligasi, deposito, emas, tanah, dan berbagai macam jenis investasi lainnya (Sari, 2019). Hilgert et al (2003) dalam Arianti (2018) menyatakan bahwa personal income adalah total pendapatan kotor tahunan seorang individu yang berasal dari upah, perusahaan bisnis dan berbagai investasi. Income adalah penghasilan pribadi sebelum pajak. Income diukur berdasarkan pendapatan dari semua sumber. Komponen terbesar dari total pendapatan adalah upah dan gaji. Selain itu, ada banyak kategori lain pendapatan, termasuk pendapatan sewa, pembayaran subsidi pemerintah, pendapatan bunga dan pendapatan dividen. Income adalah indikator yang baik untuk permintaan konsumen masa depan meskipun tidak sempurna. Menurut Mahdzan dkk (2013) semakin tinggi besarnya pendapatan seseorang maka orang tersebut akan berusaha memperoleh pemahaman bagaimana cara memanfaatkan keuangan dengan cara yang lebih baik melalui pengetahuan keuangan.

Pendapatan merupakan salah satu indikator untuk mengukur kesejahteraan seseorang atau masyarakat, sehingga pendapatan masyarakat ini mencerminkan kemajuan ekonomi suatu masyarakat. Pendapatan seseorang pada dasarnya tergantung dari pekerjaan di bidang jasa atau produksi, serta waktu jam kerja yang dicurahkan, tingkat pendapatan perjam yang diterima (Lumintang, 2013). Pendapatan adalah jumlah penghasilan yang diterima selama periode tertentu berdasarkan jenis pekerjaan, prestasi dan lamanya bekerja. Besar kemungkinan bahwa individu dengan pendapatan yang lebih akan menunjukkan perilaku manajemen keuangan lebih bertanggung jawab, mengingatnya dana yang tersedia mereka memberi mereka kesempatan untuk bertindak secara bertanggung jawab. Besar kemungkinan bahwa individu dengan pendapatan yang lebih akan menunjukkan perilaku manajemen keuangan lebih bertanggung jawab, mengingat dana yang tersedia memberi kesempatan untuk bertindak secara bertanggung jawab (Naila Al Kholilah dan Rr. Iramani, 2013). Didalam unsur-unsur pendapatan yang dimaksudkan adalah asal dari pada pendapatan itu diperoleh, dimana unsur-unsur tersebut adalah a) Pendapatan hasil produksi barang atau jasa, b) Imbalan yang diterima atas penggunaan aktiva sumber-sumber ekonomis perusahaan oleh pihak lain, c) Penjualan aktiva diluar barang dagangan merupakan unsur - unsur pendapatan lain-lain suatu perusahaan. Adapun indikator tingkat pendapatan dalam penelitian ini yaitu unsur - unsur pendapatan, sumber - sumber pendapatan dan biaya (Arianti, 2018).

\section{Keputusan Berinvestasi}

Berinvestasi merupakan hal yang sangat penting dalam mengelola pendapatan, dengan berinvestasi seseorang akan mendapatkan keuntungan yang tinggi dengan risiko yang tinggi pula, begitupun sebaliknya.Investasi adalah aktivitas penempatan modal ke dalam sebuah usaha tertentu dengan tujuan memperoleh tambahan penghasilan dan keuntungan (Dewi Ayu dan Rr. Iramani, 2014). Keputusan dalam berinvestasi adalah keputusan yang penting dalam pengelolaan keuangan. Menurut Manurung (2012) dalam konteks keputusan investasi, seorang pengambil keputusan yang menerima umpan balik negatif atas keputusan investasi sebelumnya akan berada pada posisi atau kondisi rugi, dan akan memandang keputusan berikutnya sebagai pilihan antara kerugian pasti yang telah terjadi (yaitu memilih untuk tidak melanjutkan tindakan menambah investasi) dengan kerugian di masa mendatang yang kurang pasti (yaitu mengambil risiko menambah dana dengan harapan mendapat pengembalian positif). Seseorang dalam melakukan investasi tidak saja hanya menggunakan estimasi atas prospek instrumen investasi, tetapi faktor psikologi sudah ikut menentukan investasi tersebut. Menurut Tandellin dalam Marsis (2013) dalam Putri dan Hamidi (2019) bahwa indikator keputusan investasi adalah a) Return (tingkat pengembalian), b) Risk (risiko), c) The Time Factor (waktu). 
Gambar model penelitian dibawah ini menerangkan atau mengetahui apakah keputusan berinvestasi dapat memediasi atau tidak dapat memediasi pengaruh pendapatan dan perilaku keuangan terhadap literasi keuangan atau apakah variabel intervening tersebut mampu memediasi hubungan variabel independen terhadap variabel dependen karena analisis jalur adalah penggunaan analisis untuk menaksir hubungan kausalitas antar variabel (model causal) yang telah ditetapkan sebelumnya berdasarkan teori, (Ghozali, 2011).

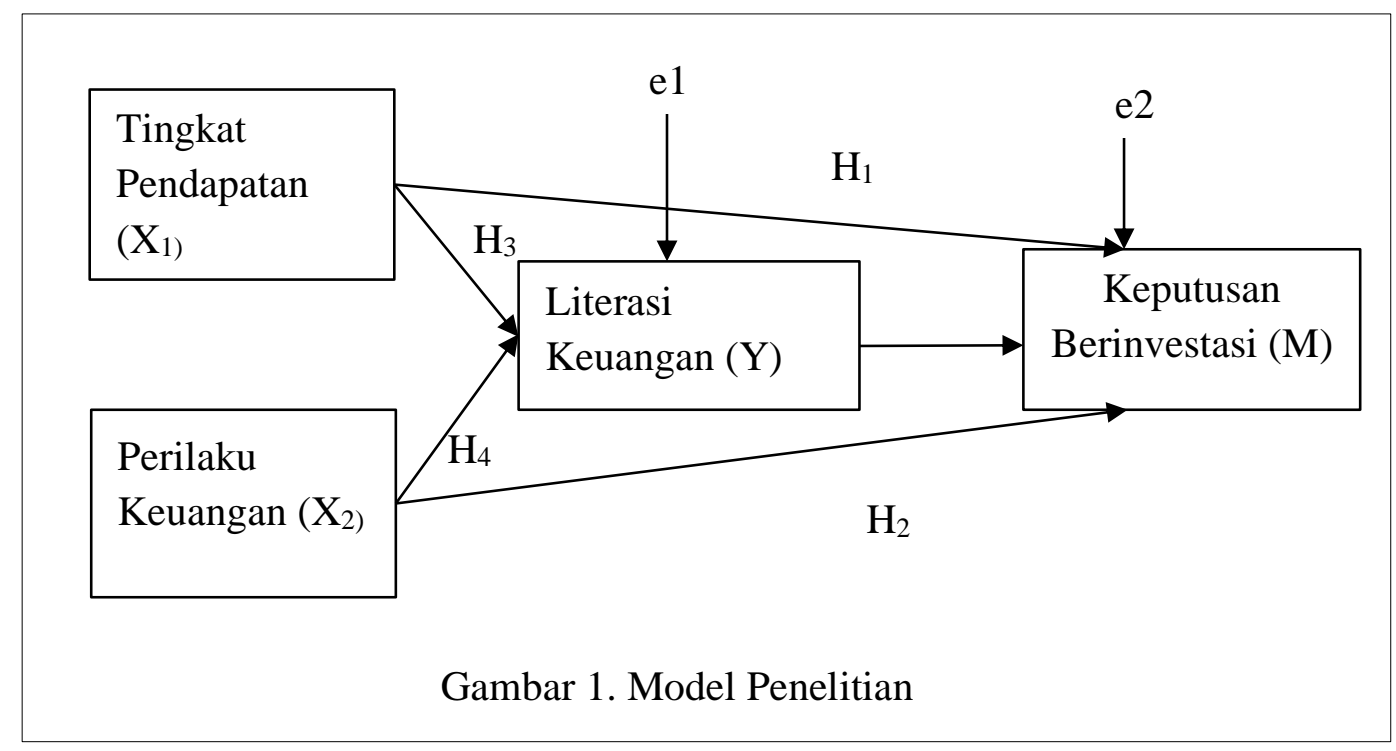

\section{Pengembangan Hipotesis}

\section{Pengaruh Pendapatan Terhadap Literasi Keuangan}

Literasi keuangan terdiri dari sejumlah kemampuan dan pengetahuan mengenai keuangan yang dimiliki oleh seseorang untuk mampu mengelola atau menggunakan sejumlah uang untuk meningkatkan taraf hidupnya dan bertujuan untuk mencapai kesejahteraan (Arianti, 2018). Pendapatan usaha yang tinggi akan mendorong peningkatan penggunaan produk perbankan. Selain meningkatkan pengetahuan mengenai produk perbankan itu sendiri, pelaku usaha juga akan mengetahui tentang arus kas dari usaha yang dijalani. Hal tersebut secara tidak langsung juga akan mempengaruhi pengetahuan keuangan umum dari pelaku usaha. Semakin besar pendapatan usaha, pelaku usaha akan memiliki cadangan dana yang lebih besar. Apabila tidak digunakan untuk pengembangan usaha utama, dana tersebut dapat dimanfaatkan untuk mendapat penghasilan tambahan, salah satunya melalui penggunaan produk investasi. Maraknya investasi bodong mengharuskan pelaku usaha yang memiliki minat untuk berinvestasi untuk mencari informasi mengenai investasi agar tidak menjadi korban penipuan. Adanya pencarian informasi agar investasi yang dipilih tepat dan sesuai akan meningkatkan literasi keuangan dimensi investasi pada pelaku usaha. Pendapatan merupakan inflow of assets akibat penjualan barang dan/atau jasa ke dalam perusahaan. Pada penelitian ini pendapatan usaha diukur melalui pendapatan rata-rata per bulan dalam satuan jutaan rupiah. Pelaku UMKM yang memiliki pendapatan usaha lebih tinggi akan cenderung memiliki literasi keuangan yang lebih tinggi. Orang yang memiliki tingkat pendapatan usaha lebih tinggi akan cenderung memiliki kemampuan untuk merencakan dan mengontrol keuangannya dengan baik. Hal ini dikarenakan dengan semakin tingginya pendapatan usaha, akan semakin banyak aset yang harus dikelola oleh pelaku UMKM. Semakin tinggi 
pendapatan seseorang, maka orang tersebut akan berusaha mencari informasi dan pemahaman untuk memanfaatkan uang yang dimilikinya. Pendapatan yang lebih tinggi menunjukkan kesempatan yang lebih besar kepada seseorang untuk lebih bertanggung jawab terkait dengan ketersediaan dana yang dimilikinya. Hasil penelitian ini sejalan dengan hasil penelitian Suryanto dan Rasmini (2018) yang menyatakan tingkat pendapatan berpengaruh positif terhadap literasi keuangan. Pernyataan yang tidak jauh berbeda diungkapkan oleh The Australia and New Zealand Banking Group Limited dalam ANZ (2015) yang menyebutkan faktor yang mempengaruhi literasi keuangan adalah usia, pengetahuan keuangan dan numerik sikap keuangan, pendapatan rumah tangga serta pendidikan dan jabatan. Berdasarkan uraian tersebut, maka hipotesis yang dikembangkan adalah:

$H_{1} \quad$ : Di duga ada pengaruh pendapatan terhadap literasi keuangan

\section{Pengaruh Perilaku Keuangan Terhadap Literasi Keuangan}

Pemahaman tentang perilaku keuangan akan membantu seseorang untuk mengerti apa yang dipercaya terkait hubungan dirinya dengan uang. Oleh sebab itu, pengertian perilaku keuangan diartikan sebagai keadaan pikiran, pendapat, serta penilaian tentang keuangan. Menurut Rahmayanti dkk., (2019) mengatakan bahwa perilaku keuangan berhubungan dengan tanggung jawab keuangan seseorang terkait dengan cara pengelolaan keuangan. Karena penelitian ini menunjukkan bahwa seseorang umumnya tidak memiliki pemahaman besar tentang tingkat pengetahuan keuangan, ketika pengetahuan keuangan dilihat secara obyektif dan subyektif. Hasil ini menunjukkan bahwa sebagian orang percaya bahwa mereka memiliki banyak pengetahuan berperilaku keuangan yang baik dan rasional daripada seseorang yang memiliki tingkat pengetahuan sedikit (Aminatuzahra, 2014). Penelitian ini sesuai dengan penelitian yang dilakukan oleh Chaulagain (2015) menunjukkan bahwa kesejahteraan finansial masyarakat tergantung pada peningkatan perilaku keuangan sedangkan perilaku tersebut dikontribusikan oleh literasi keuangan. Jadi dapat disimpulkan bahwa perilaku keuangan berpengaruh signifikan terhadap literasi keuangan. Selanjutnya penelitian ini juga sesuai dengan penelitian Rahmayanti dkk., (2019) menunjukkan bahwa perilaku keuangan berpengaruh positif signifikan terhadap literasi keuangan. Berdasarkan uraian tersebut, maka hipotesis yang dikembangkan adalah:

$\mathrm{H}_{2}$ : Di duga ada pengaruh prilaku keuangan terhadap literasi keuangan

\section{Pendapatan Berpengaruh Langsung Terhadap Literasi Keuangan Melalui Keputusan Berinvestasi}

Pendapatan merupakan inflow of assets akibat penjualan barang dan/atau jasa ke dalam perusahaan. Pada penelitian ini pendapatan usaha diukur melalui pendapatan rata-rata per bulan dalam satuan jutaan rupiah. Pelaku UMKM yang memiliki pendapatan usaha lebih tinggi akan cenderung memiliki literasi keuangan yang lebih tinggi. Orang yang memiliki tingkat pendapatan usaha lebih tinggi akan cenderung memiliki kemampuan untuk merencakan dan mengontrol keuangannya dengan baik. Hal ini memiliki makna bahwa semakin baik pendapatan maka semakin tinggi pendapatan maka semakin baik dan bertanggungjawab perilaku keuangannya. John et al, (2009) dalam Putri dan Rahyuda (2017) menyatakan bahwa terdapat hubungan yang positif antara pendapatan (income) dengan perilaku manajemen keuangan yang bertanggungjawab yang berarti semakin tinggi pendapatan maka semakin baik dan bertanggungjawab perilaku keuangannya. Hasil penelitian ini didukung oleh teori perpsektif perilaku keuangan dalam pengambil keputusan keuangan yang adaptif berarti bahwa sifat keputusan dan lingkungan di mana itu membuat pengaruh jenis proses yang digunakan. Semakin baik keadaan sosiodemografi seseorang akan 
berpengaruh terhadap jenis proses pengambilan keputusan investasi yang digunakan kearah yang baik. V. Sudheer (2015) dalam Putri dan Isbanah (2020) menemukan hasil bahwa pendapatan berpengaruh signifikan terhadap kebutuhan serta keputusan investasi. Kemudian penelitian ini juga dilakukan oleh penelitian Dewi dan Purbawangsa (2018) menunjukkan bahwa hasil data statistik variabel literasi keuangan memiliki pengaruh paling besar dalam menentukan perilaku keputusan investasi dibandingkan pendapatan. Berdasarkan uraian di atas, dapat dinyatakan hipotesis sebagai berikut:

$\mathrm{H}_{3}$ : Di duga Pendapatan berpengaruh langsung terhadap literasi keuangan melalui keputusan berinvestasi

\section{Perilaku Keuangan Berpengaruh Langsung Terhadap Literasi Keuangan Melalui Keputusan Berinvestasi}

Investasi merupakan suatu kegiatan menanamkan modal guna mendapatkan profit. Byrne (2007) dalam Sari (2019) juga menemukan bahwa pengetahuan keuangan yang rendah akan menyebabkan perilaku keuangan yang rendah pula dan akan berdampak pada pembuatan rencana keuangan yang salah, dan menyebabkan bias dalam pencapaian kesejahteraan di saat usia tidak produktif lagi. Dalam hal ini literasi keuangan sangat berpengaruh penting terhadap keputusan seseorang dalam berinvestasi. Selain itu kemampuan pengetahuan yang luas akan memudahkan seseorang mengambil keputusan untuk berinvestasi dan literasi keuangan ini penting dalam mengelola keuangan dengan baik. Seseorang yang memutuskan untuk berinvestasi, pastinya akan ber-pengaruh lebih baik dalam segi pengelolaan keuangan. Penelitian ini sejalan dengan penelitian Putri dan Rahyuda (2017) mengatakan bahwa pengaruh variabel financial literacy berbanding lurus dengan perilaku keputusan investasi individu artinya semakin tinggi financial literacy seseorang, maka semakin baik perilaku keputusan investasi individunya. Kusnandar dan Kurniawan (2018) menujukkan bahwa literasi keuangan tidak berpengaruh terhadap perilaku keuangan Ibu rumah tangga di kota Tasikmalaya dan gaya hidup mampu memediasi pengaruh literasi keuangan terhadap perilaku keuangan Ibu rumah tangga di kota Tasikmalaya Sedangkan Berdasarkan uraian di atas, dapat dinyatakan hipotesis sebagai berikut :

$H_{4}$ : Di duga perilaku keuangan berpengaruh langsung terhadap literasi keuangan melalui keputusan berinvestasi

\section{METODE PENELITIAN}

Desain penelitian yang digunakan dalam penelitian ini adalah dengan menggunakan pendekatan kuantitatif metode deskriptif. Objek dalam penelitian ini adalah keputusan investasi yang terdiri dari tiga aspek, yaitu literasi keuangan, perilaku keuangan dan pendapatan. Subjek dari penelitian ini adalah pelaku UMKM di dinas koperasi dan UMKM kota Tangerang Selatan. 
Tabel 2. Operasional Variabel

\begin{tabular}{|c|c|c|c|c|}
\hline No. & Variabel & Konsep & Indikator & Skala \\
\hline 1. & $\begin{array}{l}\text { Literasi } \\
\text { keuangan } \\
\text { (Remund, } \\
\text { 2010) }\end{array}$ & $\begin{array}{lr}\text { Literasi } & \begin{array}{r}\text { keuangan } \\
\text { dapat diartikan }\end{array} \\
\text { sebagai pengetahuan } \\
\text { dan pemahaman } \\
\text { mengenai konsep } \\
\text { keuangan } \\
\text { yang memiliki tujuan } \\
\text { untuk } \\
\text { mencapai } \\
\text { kesejahteraan. }\end{array}$ & $\begin{array}{l}\text { a. Pengetahuan tentang } \\
\text { konsep keuangan } \\
\text { b. Saving dan pinjaman } \\
\text { c. Asuransi } \\
\text { d. Investasi }\end{array}$ & Ordinal \\
\hline 2. & $\begin{array}{l}\text { Perilaku } \\
\text { Keuangan } \\
\text { (Nababan, } \\
\text { 2012) }\end{array}$ & $\begin{array}{l}\text { Kemampuan } \\
\text { seseorang dalam } \\
\text { mengatur } \\
\text { (perencanaan, } \\
\text { penganggaran, } \\
\text { pemeriksaan, } \\
\text { pengelolaan, } \\
\text { pengendalian, } \\
\text { pencarian dan } \\
\text { penyimpanan) dana } \\
\text { keuangan sehari-hari. }\end{array}$ & $\begin{array}{l}\text { a. Membayar tagihan } \\
\text { tepat waktu. } \\
\text { b. Membuat anggaran } \\
\text { pengeluaran dan } \\
\text { belanja } \\
\text { c. Mencatat pengeluaran } \\
\text { dan belanja (harian, } \\
\text { bulanan, dan lain-lain) } \\
\text { d. Menyediakan dana } \\
\text { untuk pengeluaran } \\
\text { tidak terduga. } \\
\text { e. Menabung secara } \\
\text { periodik. } \\
\text { f. Membandingkan harga } \\
\text { antar toko atau } \\
\text { swalayan atau } \\
\text { supermarket sebelum } \\
\text { memutuskan untuk } \\
\text { melakukan pembelian }\end{array}$ & Ordinal \\
\hline 3. & $\begin{array}{l}\text { Pendapatan } \\
\text { (Dica Suci } \\
\text { Engga Jati, } \\
\text { 2015) }\end{array}$ & $\begin{array}{l}\text { Jumlah penghasilan } \\
\text { yang diterima selama } \\
\text { periode tertentu } \\
\text { berdasarkan jenis } \\
\text { pekerjaan, prestasi dan } \\
\text { lamanya bekerja }\end{array}$ & $\begin{array}{l}\text { a. Unsur - unsur } \\
\text { pendapatan } \\
\text { b. Sumber pendapatan } \\
\text { c. Biaya }\end{array}$ & Ordinal \\
\hline 4. & $\begin{array}{l}\text { Keputusan } \\
\text { Berinvestasi } \\
\text { (Marsis, } \\
\text { 2013) }\end{array}$ & $\begin{array}{l}\text { Investasi merupakan } \\
\text { suatu bentuk } \\
\text { pengorbanan kekayaan } \\
\text { di masa sekarang } \\
\text { untuk mendapatkan } \\
\text { keuntungan di masa } \\
\text { depan dengan tingkat } \\
\text { resiko tertentu. }\end{array}$ & $\begin{array}{l}\text { a. Return/tingkat } \\
\text { pengembalian } \\
\text { investasi } \\
\text { b. Risk (risiko) } \\
\text { c. The time factor } \\
\text { (jangka waktu) }\end{array}$ & Ordinal \\
\hline
\end{tabular}


Jumlah objek penelitian ini yaitu seluruh para pelaku UMKM di kota Tangerang Selatan dengan jumlah populasi sebanyak 23.000 pelaku UMKM pada tahun 2017. Dengan populasinya yang heterogen, data yang dikumpulkan pada waktu tertentu saja untuk menggambarkan kondisi populasi. Penentuan ukuran sampel dalam penelitian ini dengan menggunakan metode simple random sampling yaitu rumus slovin. Simple random sampling adalah pengambilan anggota sampel dan populasi yang dilakukan secara acak tanpa memperhatikan strata yang ada dalam populasi tersebut. Teknik pengambilan sampel dengan menggunakan rumus Slovin adalah sebagai berikut:

$$
\mathrm{n}=\frac{\mathrm{N}}{1+\left(\mathrm{NX} \mathrm{e}^{\mathrm{x}}\right)}
$$

Di mana:

$$
\begin{array}{ll}
\mathrm{n} & =\text { Ukuran sampel } \\
\mathrm{N} & =\text { Populasi } \\
\mathrm{e} & =\text { Taraf Kesalahan sebesar 0,05\% (5\%) }
\end{array}
$$

Dari rumus diatas, maka besarnya jumlah sampel (n) adalah sebagai berikut :

$$
\begin{aligned}
& n=\frac{23.000}{1+23.000(0,05)^{2}} \\
& n=\frac{23.000}{58,5}=393.16
\end{aligned}
$$

Berdasarkan hasil perhitungan diatas, diperoleh besarnya sampel sebanyak 393 pelaku UMKM. Kelemahan dari teknik penarikan sampel dengan cara ini adalah sampel yang terpilih kemungkinan besar tidak mewakili populasi, sehingga generalisasi yang dapat dilakukan oleh peneliti akan terbatas. Cara ini cenderung memiliki bias yang tinggi karena peneliti menentukan sendiri responden yang terpilih secara acak yang biasanya secara subjektif. Namun subjektifitas ini dapat direduksi berdasarkan asumsi bahwa pelaku UMKM memiliki karakteristik yang serupa. Karena jumlah populasi yang besar dan tidak adanya kerangka sampel serta keterbatasan waktu dan tenaga maka teknik penarikan sampel merupakan cara terbaik untuk mendapatkan data yang diinginkan.

Untuk menentukan siapa saja yang akan dijadikan responden dalam penelitian ini menggunakan metode nonprobability sampling. Non-probability sampling merupakan teknik pengambilan sampel yang tidak memberikan peluang atau kesempatan yang sama bagi setiap unsur atau anggota populasi untuk dipilih menjadi anggota sampel (Sugiyono, 2013). Teknik yang digunakan adalah sampling aksidental. Teknik sampling aksidental adalah teknik penentuan sampel berdasarkan faktor spontanitas, artinya siapa saja yang secara tidak sengaja bertemu dengan peneliti dan sesuai dengan karakteristik (ciri-cirinya), maka orang tersebut dapat digunakan sebagai sampel (Akdon dan Riduwan, 2013). Teknik aksidental ini dilakukan dengan quota per wilayah dimana pandangan cocok atau tidaknya adalah berdasarkan karakteristik sebagai berikut :

1. Pelaku UMKM yang hanya di wilayah Tangerang Selatan.

2. Bersedia mengisi kuisioner untuk keperluan riset.

3. Yang bersedia mengikuti penyuluhan Dinas Koperasi dan UKM Tangerang Selatan 
Data yang digunakan dalam penelitian ini berupa data primer dan data sekunder. Sumber data primer didapatkan dari penyebaran kuesioner kepada seluruh pelaku UMKM kota Tangerang Selatan yang menjadi populasi penelitian ini. Sumber data sekunder (pendukung) yaitu berupa dokumen-dokumen yang dimiliki oleh dinas pemerintah kota tangerang selatan yang berkaitan dengan sektor UMKM dan data pendukung lainnya yaitu media massa, BPS, hasil penelitian terdahulu, buku dan referensi lainnya yang terkait dengan penelitian ini. Dalam penelitian ini data primer didapat dari sumber pertama, yaitu pelaku UMKM kota Tangerang Selatan. Teknik pengumpulan data primer tersebut pada penelitian ini adalah Observasi, Studi Kepustakaan (Library Research), Kuesioner / Angket merupakan tehnik pengumpulan data yang dilakukan dengan cara memberi seperangkat pertanyaan atau pernyataan tertulis kepada responden untuk dijawab dengan menggunakan skala likert. Untuk setiap pilihan jawaban yang diberikan oleh responden, akan diberi skor mulai dari 1 - 5. Skor tersebut akan menggambarkan apakah responden setuju atau tidak dengan pernyataan-pernyataan yang terdapat pada kuesioner yang diberikan.

\section{Teknik Analisa Data}

Dalam penelitian ini peneliti menggunakan teknis analisis jalur (Path Analysis) dengan bantuan software SPSS 25.0. Analisis jalur digunakan untuk menguji hipotesis yang telah diajukan dan untuk menguji pengaruh variabel mediasi (variabel intervening) dalam memediasi variabel independen terhadap variabel dependen. (Ghozali, 2011). Maka model persamaan regresinya diformulasikan sebagai berikut:

1. Persamaan substruktur 1

$$
\mathrm{Y}=\rho \mathrm{YX}_{1} \mathrm{X}_{1}+\rho \mathrm{YX}_{2} \mathrm{X}_{2}+\rho \mathrm{Y} \epsilon_{1} \epsilon_{1}
$$

2. Persamaan substruktur 2

$$
M=\rho M X_{1} X_{1}+\rho M X_{2} X_{2}+\rho M Y Y+\rho M \epsilon_{2} \epsilon_{2}
$$

Untuk mengetahui kebenaran prediksi dari pengujian regresi yang dilakukan, maka ada tiga pengujian yang dapat dilakukan. Diantaranya adalah koefisien determinasi $\left(R^{2}\right)$, uji $F$ dan uji T.

Uji intervening dilakukan dengan uji Sobel untuk membuktikan apakah keputusan berinvestasi dapat memediasi pengaruh pendapatan dan perilaku keuangan terhadap literasi keuangan. Uji Sobel ini dilakukan dengan cara menguji kekuatan pengaruh tidak langsung variabel independen (X) kepada variabel dependen (Y) melalui variabel mediasi (intervening) (M). Pengaruh tidak langsung anatar variabel $\mathrm{X}$ ke $\mathrm{Y}$ melalui $\mathrm{M}$ dihitung dengan cara mengalikan jalur $\mathrm{X} \rightarrow \mathrm{M}$ (a) dengan jalur $\mathrm{M} \rightarrow \mathrm{Y}(\mathrm{b})$ atau ab. Jadi koefisien $\mathrm{ab}=\left(\mathrm{c}-\mathrm{c}^{\prime}\right)$, di mana $\mathrm{c}$ adalah pengaruh $\mathrm{X}$ terhadap Y tanpa mengontrol M, sedangkan c' adalah koefisien pengaruh X terhadap Y setelah mengontrol M. Standart error koefisien a ditulis dengan Sa dan standart error koefisien b ditulis dengan Sb. Besarnya standart error pengaruh tidak langsung (indirect effect) atau ditulis dengan Sab, dihitung dengan rumus berikut ini :

$$
S a b=\sqrt{b^{2} S a^{2}+a^{2} S b^{2}+S a^{2} S b^{2}}
$$

Untuk menguji signifikansi pengaruh tidak langsung (indirect effect), maka perlu dihitung nilai t dari koefisien ab dengan rumus :

$$
t=\frac{a b}{S a b}
$$

Nilai t hitung ini dibandingkan dengan nilai t tabel. Jika nilai t hitung > nilai t tabel maka dapat disimpulkan bahwa terjadi pengaruh mediasi 


\section{HASIL DAN PEMBAHASAN}

\section{Analisis Deskriptif}

Hasil analisis data deskriptif sebagai berikut :

\begin{tabular}{lcrrrrr} 
& \multicolumn{2}{c}{ Tabel 3. Analisis Deskriptif } & & \\
& N & Minimum & Maximum & Mean & Std. Deviation \\
\hline Pendapatan & 249 & 11 & 30 & 22.15 & 4.249 \\
\hline Perilaku Keuangan & 249 & 11 & 55 & 42.22 & 7.384 \\
\hline Literasi Keuangan & 249 & 27 & 90 & 66.77 & 10.054 \\
\hline Keputusan Berinvestasi & 249 & 8 & 40 & 30.91 & 5.147 \\
\hline Valid N (listwise) & 249 & & & & \\
\hline
\end{tabular}

Berdasarkan tabel 3 menunjukkan jumlah responden (n) sebanyak 249 responden. Nilai minimum menunjukkan jawaban responden paling sedikit dan maksimum merupakan jawaban paling tinggi. Literasi keuangan (Y) nilai minimum adalah sebesar 27, maksimum adalah 90 dan mean sebesar 66,77 dengan standar deviasi 10,054. Pendapatan (X1) mempunyai nilai minimum sebesar 11, maksimum sebesar 30 dan mean sebesar 22,15 dengan standar deviasi 4,249. Variabel perilaku keuangan (X2) mempunyai nilai minimum sebesar 11 maksimum sebesar 55 dan mean sebesar 42,22 dengan standar deviasi 7.384. Sedangkan variabel intervening yaitu keputusan berinvestasi (M) memiliki nilai minimum sebesar 8, maksimum sebesar 40, mean sebesar 30,91 dan standar deviasi 5,147.

\section{Uji Validitas Dan Reliabilitas Data}

Uji validitas digunakan untuk mengukur valid atau tidaknya suatu kuesioner yang disebar kepada responden. Untuk mengetahui valid atau tidaknya suatu kuesioner maka nilai $r_{\text {hitung }}$ harus lebih besar dari $r_{\text {tabel. }}$. Dengan tingkat signifikan sebesar 5\%, maka $r_{\text {tabel }}$ yang digunakan pada penelitian ini adalah 0,124 . kemudian hasil uji reliabilitas pada seluruh variabel mempunyai nilai yang lebih besar dari 0,70 . Maka semua variabel - variabel dalam penelitian ini sudah memenuhi kriteria reliabel. Responden pada penelitian ini merupakan pelaku UMKM Di Kota Tangerang Selatan yang tersebar di tujuh kecamatan yaitu Kecamatan Ciputat Timur, Ciputat, Serpong, Serpong Utara, Pamulang, Setu dan Pondok Aren.

\section{Uji Asumsi Klasik}

Uji normalitas dibuktikan dengan beberapa cara, diantaranya dengan melihat grafik normal p-plot.

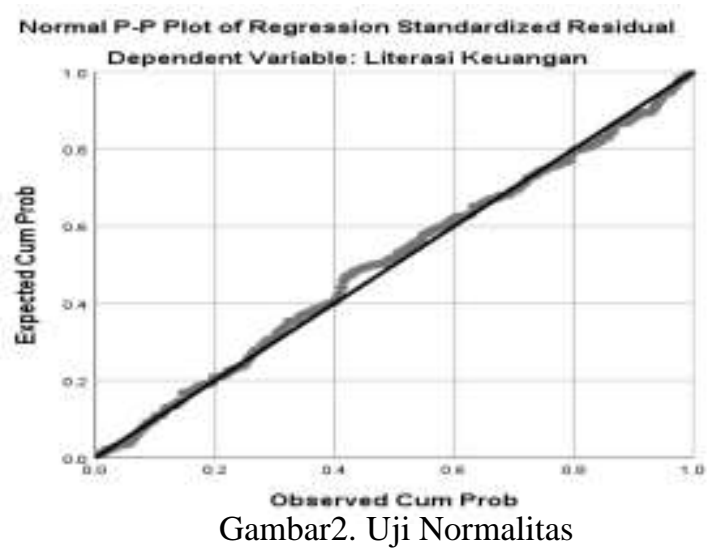


Berdasarkan tampilan uji normalitas dengan p-plot pada gambar 3 dapat dilihat data tersebar disekitar garis diagonal dan mengikuti pola garis diagonal tersebut, maka data tersebut dapat dikatakan berdistribusi normal. Kemudian uji normalitas juga menggunakan tabel yaitu uji Kolmogorov Smirnov dapat dilihat pada tabel 4 dibawah ini:

Tabel 4. Hasil Uji One-Sample Kolmogorov-Smirnov Test

\begin{tabular}{llr}
\multicolumn{2}{c}{ Tabel 4. Hasil Uji One-Sample Kolmogorov-Smirnov Test } \\
\multicolumn{1}{c}{} & & Unstandardized Residual \\
\hline $\mathrm{N}$ & & 249 \\
\hline Normal Parameters & Mean & .0000000 \\
\cline { 2 - 3 } & Std. Deviation & 8.72566654 \\
\hline Most Extreme Differences & Absolute & .053 \\
\cline { 2 - 3 } & Positive & .035 \\
\cline { 2 - 3 } & Negative & -.053 \\
\hline Test Statistic & & .053 \\
\hline Asymp. Sig. (2-tailed) & & $.088^{\mathrm{c}}$ \\
\hline
\end{tabular}

a. Test distribution is Normal.

b. Calculated from data.

c. Lilliefors Significance Correction.

Berdasarkan tabel 4 diatas menunjukkan bahwa nilai signifikansi menunjukkan angka 0,088 $>0,05$. Maka dapat dikatakan bahwa data yang digunakan dalam penelitian ini berdistribusi normal.

Tabel 5. Hasil Uji Multikolinearitas Coefficients $^{\mathrm{a}}$

\begin{tabular}{l|r|r} 
& \multicolumn{2}{|c}{ Collinearity Statistics } \\
Model & Tolerance & \multicolumn{1}{c}{ VIF } \\
\hline 1 (Constant) & & \\
\hline Pendapatan & .645 & 1.551 \\
\hline Perilaku Keuangan & .513 & 1.951 \\
\hline Keputusan & .593 & 1.685 \\
Berinvestasi & & \\
\hline
\end{tabular}

a. Dependent Variable: Literasi Keuangan

Berdasarkan tabel 5 diatas bahwa uji multikolinearitas dibuktikan dengan melihat nilai tolerance dan Variance Inflation Factor (VIF). Nilai cutoff yang umum digunakan dalam menunjukkan adanya multikolinearitas adalah nilai tolerance $\leq 0,10$ atau nilai VIF $\geq 10$ (Ghozali, 2012). Maka dapat dikatakan multikolineritas.

Deteksi terhadap masalah heteroskedastisitas juga dilakukan dengan melihat grafik plot nilai prediksi variabel dependen (ZPRED) dengan residunya variabel independen (SRESID). Uji heteroskedastisitas dalam penelitian ini juga menggunakan uji Glejser dengan nilai signifikansi diatas tingkat kepercayaan 5\% atau 0,05 . 


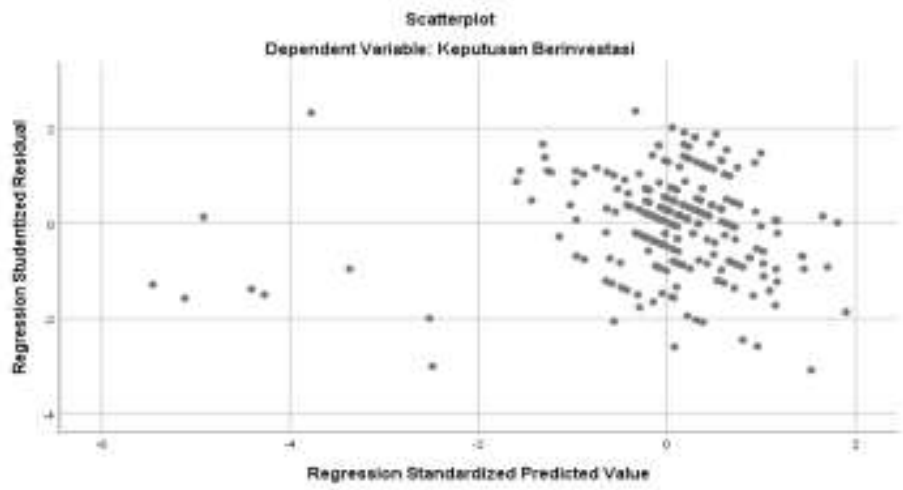

Gambar 3. Hasil Uji Heteroskedastisitas

Berdasarkan grafik scatterplots yang terlihat diatas menunjukkan bahwa titik-titik menyebar secara acak dan tidak membentuk pola, serta tersebar dibawah maupun diatas angka 0 pada sumbu y. Hal ini dapat disimpulkan bahwa pada data penelitian tersebut tidak terjadi heteroskedastisitas. Kemudian uji heteroskedastisitas dalam penelitian ini juga menggunakan uji Glejser sebagai berikut:

\begin{tabular}{|c|c|c|c|c|c|c|}
\hline \multirow[b]{2}{*}{ Mod } & & \multicolumn{2}{|c|}{$\begin{array}{l}\text { Coefficients }^{\mathrm{a}} \\
\text { Unstandardized } \\
\text { Coefficients }\end{array}$} & \multirow{2}{*}{$\begin{array}{c}\text { Standardized } \\
\text { Coefficients } \\
\text { Beta }\end{array}$} & \multirow[b]{2}{*}{$\mathrm{t}$} & \multirow[b]{2}{*}{ Sig. } \\
\hline & & $\mathrm{B}$ & $\begin{array}{l}\text { Std. } \\
\text { Error }\end{array}$ & & & \\
\hline \multirow[t]{4}{*}{1} & (Constant) & 3.743 & 1.197 & & 3.127 & .002 \\
\hline & Pendapatan & .069 & .040 & .120 & 1.702 & .090 \\
\hline & Perilaku Keuangan & -.037 & .025 & -.113 & -1.518 & .130 \\
\hline & Literasi Keuangan & -.009 & .018 & -.038 & -.533 & .595 \\
\hline
\end{tabular}

a. Dependent Variable: ABS_RES

Berdasarkan tabel 6 diatas, bahwa seluruh variabel menunjukkan hasil nilai signifikansi diatas 0,05. Maka dapat disimpulkan secara keseluruhan bahwa data tersebut tidak terjadi heteroskedastisitas.

\section{Analisis Regresi Model I}

Uji ini dilakukan dengan menggunakan analisis regresi berganda dan analisis jalur dengan bantuan SPSS 25.0. Analisis regresi dilakukan dua kali karena terdapat dua model regresi pada penelitian ini. Sedangkan analisis jalur dilakukan untuk mengetahui pengaruh langsung maupun tidak langsung antar variabel.

a) Koefisien Determinasi $\left(\mathrm{R}^{2}\right)$

Tabel 7 Hasil Uji Koefisien Determinasi $\left(R^{2}\right)$ (Model I)

Model Summary

\begin{tabular}{ll|r|r|r}
\hline Model & R & R Square & $\begin{array}{c}\text { Adjusted R } \\
\text { Square }\end{array}$ & $\begin{array}{c}\text { Std. Error of the } \\
\text { Estimate }\end{array}$ \\
\hline 1 & $.479^{\mathrm{a}}$ & .230 & .224 & 8.859 \\
\hline
\end{tabular}

a. Predictors: (Constant), Perilaku Keuangan, Pendapatan 
Berdasarkan hasil uji statistik koefisien determinasi $\left(R^{2}\right)$ pada tabel 7 diatas menunjukkan bahwa nilai R square adalah 0,230 atau 23,0\%. Kemudian untuk Adjusted $R$ Square sebesar 0,224 atau $22,4 \%$. Sisanya sebesar $77,6 \%$ dipengaruhi oleh variabel lain yang belum diteliti dalam penelitian ini.

b) Uji F

Tabel 8. Hasil Uji F (Model I)

ANOVA $^{a}$

\begin{tabular}{llr|r|r|c|c}
\hline Model & Sum of Squares & df & Mean Square & F & Sig. \\
\hline \multirow{2}{*}{1} & Regression & 5761.967 & 2 & 2880.984 & 36.710 & $.000^{\mathrm{b}}$ \\
\cline { 2 - 7 } & Residual & 19305.985 & 246 & 78.480 & & \\
\cline { 2 - 7 } & Total & 25067.952 & 248 & & & \\
\hline
\end{tabular}

a. Dependent Variable: Literasi Keuangan

b. Predictors: (Constant), Perilaku Keuangan, Pendapatan

Berdasarkan hasil tersebut, dapat dilihat bahwa nilai F-hitung adalah sebesar 36,710 atau lebih besar dari nilai F-tabel yaitu sebesar 2,408 serta memiliki nilai signifikan sebesar 0,000 atau kurang dari 0,05, sehingga dapat disimpulkan bahwa variabel pendapatan dan perilaku keuangan secara simultan (bersama-sama) berpengaruh signifikan terhadap literasi keuangan.

c) Uji T

Tabel 9. Hasil Uji T (Model I)

Coefficients $^{\mathrm{a}}$

\begin{tabular}{|c|c|c|c|c|c|c|}
\hline \multirow{2}{*}{\multicolumn{2}{|c|}{ Model }} & \multicolumn{2}{|c|}{$\begin{array}{l}\text { Unstandardized } \\
\text { Coefficients }\end{array}$} & \multirow{2}{*}{$\begin{array}{c}\text { Standardized } \\
\text { Coefficients } \\
\text { Beta } \\
\end{array}$} & \multirow[b]{2}{*}{$\mathrm{t}$} & \multirow[b]{2}{*}{ Sig. } \\
\hline & & $\mathrm{B}$ & Std. Error & & & \\
\hline \multirow[t]{3}{*}{1} & (Constant) & 35.752 & 3.717 & & 9.618 & .000 \\
\hline & Pendapatan & .405 & .145 & .171 & 2.797 & .006 \\
\hline & Perilaku Keuangan & .522 & .083 & .383 & 6.258 & .000 \\
\hline
\end{tabular}

a. Dependent Variable: Literasi Keuangan

Berdasarkan tabel 9 diatas, dapat dilihat bahwa variabel pendapatan memiliki nilai koefisien regresi yaitu sebesar 0,006 bernilai positif dan memiliki nilai t-hitung sebesar 2,797 > ttabel 1.969 serta memiliki nilai signifikan sebesar 0,006 >0,05 yang artinya pendapatan memiliki pengaruh signifikan terhadap literasi keuangan dan untuk variabel perilaku keuangan nilai t-hitung sebesar 6,258 > t-tabel 1.969 dengan tingkat signifikansi 0,000 yang artinya bahwa perilaku keuangan berpengaruh signifikan terhadap literasi keuangan.

\section{Analisis Regresi Model II}

a) Koefisien Determinasi (R2)

Tabel 10. Hasil Uji Koefisien Determinasi (R2) (Model II)

Model Summary

\begin{tabular}{ll|r|r|r}
\hline Model & R & R Square & Adjusted R Square & Std. Error of the Estimate \\
\hline 1 & $.648^{\mathrm{a}}$ & .420 & .413 & 3.945 \\
\hline
\end{tabular}

a. Predictors: (Constant), Literasi Keuangan, Pendapatan, Perilaku Keuangan 
PENGARUH PENDAPATAN DAN PERILAKU KEUANGAN TERHADAP LITERASI KEUANGAN MELALUI KEPUTUSAN BERINVESTASI SEBAGAI VARIABEL INTERVENING

Baiq Fitri Arianti

Berdasarkan tabel 10 diatas, dapat dilihat bahwa nilai koefisien determinasi yang dinyatakan dengan R'Square adalah 0,420 atau 42\%. Artinya bahwa variabel pendapatan dan perilaku keuangan dapat dijelaskan oleh variabel literasi keuangan. Sedangkan Adjusted R Square sebesar 0,413 atau 41,3\% dan sisanya yaitu sebesar 58,7\% dijelaskan oleh variabel lain yang tidak diteliti.

b) Uji F

Table 11. Hasil Uji F (Model II)

ANOVA $^{\mathrm{a}}$

\begin{tabular}{lll|r|r|r|r}
\hline \multirow{2}{*}{ Model } & $\begin{array}{c}\text { Sum of } \\
\text { Squares }\end{array}$ & df & Mean Square & \multicolumn{1}{c|}{ F } & \multicolumn{1}{c}{ Sig. } \\
\hline \multirow{2}{*}{1} & Regression & 2757.103 & 3 & 919.034 & 59.052 & $.000^{\mathrm{b}}$ \\
\cline { 2 - 8 } & Residual & 3812.953 & 245 & 15.563 & & \\
\cline { 2 - 8 } & Total & 6570.056 & 248 & & & \\
\hline
\end{tabular}

a. Dependent Variable: Keputusan Berinvestasi

b. Predictors: (Constant), Literasi Keuangan, Pendapatan, Perilaku Keuangan

Berdasarkan hasil tersebut, dapat dilihat bahwa nilai F-hitung adalah sebesar 59,052 $>$ dari nilai F-tabel 2,408 serta memiliki nilai signifikan sebesar $0,000<0,05$, sehingga dapat disimpulkan bahwa variabel literasi keuangan, pendapatan dan perilaku keuangan secara simultan (bersamasama) berpengaruh signifikan terhadap variabel keputusan berinvestasi.

c) Uji T

Tabel 12. Hasil Uji T (Model II)

Coefficients $^{\mathrm{a}}$

\begin{tabular}{|c|c|c|c|c|c|c|}
\hline \multirow{2}{*}{\multicolumn{2}{|c|}{ Model }} & \multicolumn{2}{|c|}{$\begin{array}{l}\text { Unstandardized } \\
\text { Coefficients }\end{array}$} & \multirow{2}{*}{$\begin{array}{c}\text { Standardized } \\
\text { Coefficients } \\
\text { Beta } \\
\end{array}$} & \multirow[b]{2}{*}{$\mathrm{t}$} & \multirow[b]{2}{*}{ Sig. } \\
\hline & & $\mathrm{B}$ & Std. Error & & & \\
\hline \multirow[t]{4}{*}{1} & (Constant) & 25.908 & 1.942 & & 13.343 & .000 \\
\hline & Pendapatan & -.527 & .066 & -.435 & -8.039 & .000 \\
\hline & Perilaku Keuangan & .500 & .040 & .718 & 12.512 & .000 \\
\hline & Literasi Keuangan & -.067 & .028 & -.130 & -2.345 & .020 \\
\hline
\end{tabular}

a. Dependent Variable: Keputusan Berinvestasi

Berdasarkan hasil tersebut, dapat dilihat bahwa variabel literasi keuangan memiliki nilai koefisien regresi yaitu sebesar -0,527 bernilai negatif dan memiliki nilai t-hitung sebesar $-8,039 \leq$ t-tabel 1,969 serta memiliki nilai signifikan sebesar $0,000<0,05$ yang artinya pendapatan memiliki pengaruh yang negatif dan signifikan terhadap keputusan berinvestasi. Variabel perilaku keuangan memiliki nilai t-hitung sebesar 12,512 $\geq \mathrm{t}$-tabel 1,969 dengan tingkat signifikan 0,000 artinya perilaku keuangan berpengaruh positif dan signifikan terhadap keputusan berinvestasi sedangkan untuk variabel literasi keuangan memiliki nilai t-hitung sebesar $-2,345 \leq \mathrm{t}$-tabel 1,969 dengan tingkat signifikan 0,020 artinya literasi keuangan berpengaruh negatif dan signifikan terhadap keputusan berinvestasi. 


\section{Analisis Jalur (Path Analysis)}

\section{a) Koefisien Jalur Model I}

Mengacu pada output regresi model I diketahui bahwa besarnya nilai Adjusted R'Square pada tabel Model Summary adalah sebesar 0,224. Hal ini menunjukan bahwa kontribusi X1 (pendapatan) dan X2 (perilaku keuangan) terhadap literasi keuangan sebesar 22,4\% sementara sisanya 77,6\% merupakan kontribusi dari variabel-variabel lain yang tidak dimasukkan dalam penelitian. Selanjutnya, untuk mendapatkan niali e1 dapat dicari dengan menggunakan rumus e1= $\sqrt{ }(1-0,224)=0,8809$ Dengan demikian gambar diagram jalur Model I sebagai berikut:

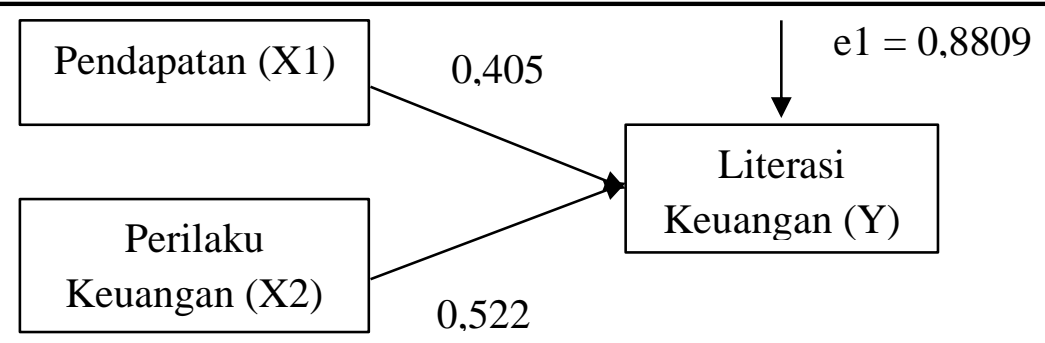

Gambar 4. Diagram Jalur Model I

\section{b) Koefisien Jalur Model II}

Mengacu pada output regresi Model II diketahui bahwa besarnya nilai adjusted R'square pada tabel Model Summary adalah sebesar 0,413 atau 41,3\% sementara sisanya 58,7\% merupakan kontribusi dari variabel-variabel lain yang tidak dimasukkan dalam penelitian. Selanjutnya, untuk mendapatkan niali e1 dapat dicari dengan menggunakan rumus e $1=\sqrt{ }(1-0,413)=0,7662$. Dengan demikian gambar diagram jalur Model II sebagai berikut :

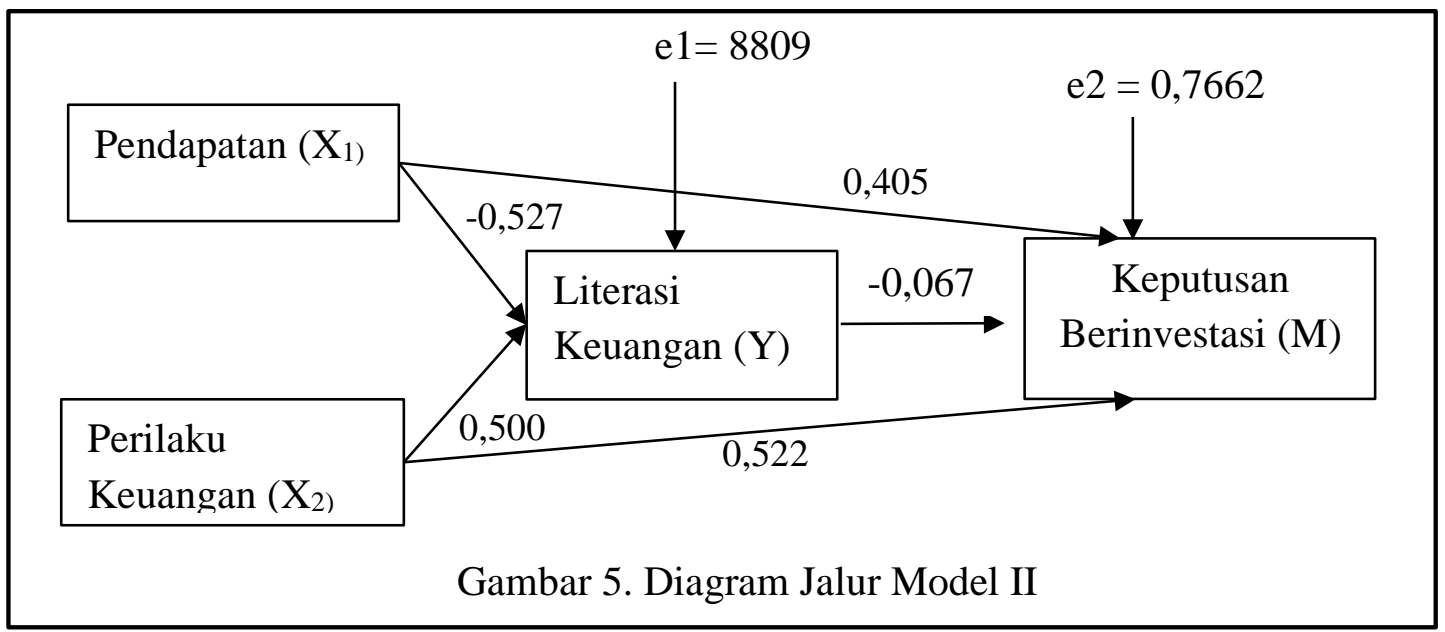

Hasil diagram jalur diatas menunjukan bahwa pendapatan (X1) dapat berpengaruh langsung ke literasi keuangan (Y) dan dapat pula berpengaruh tidak langsung yaitu dari pendapatan (X1) ke keputusan berinvestasi (M) lalu ke literasi keuangan (Y). Besarnya pengaruh langsung adalah $(0,527)$ sedangkan besarnya pengaruh tidak langsung harus dihitung dengan koefisien tidak langsung yaitu sebesar $(0,405) \times(0,067)=0,027$ dan pengaruh total yang diperoleh yaitu $(0,405)$ $+(0,027)=0,432$. Berdasarkan perhitungan tersebut diperoleh pengaruh langsung sebesar 0,527 lebih besar dari pengaruh tidak langsung sebesar 0,027 yang menunjukkan bahwa secara langsung pendapatan berpengaruh terhadap literasi keuangan melalui keputusan berinvestasi. 
Sedangkan hasil diagram jalur diatas menunjukan bahwa perilaku keuangan (X2) dapat berpengaruh langsung ke literasi keuangan (Y) dan dapat pula berpengaruh tidak langsung yaitu dari perilaku keuangan (X2) ke keputusan berinvestasi (M) lalu ke literasi keuangan (Y). Besarnya pengaruh langsung adalah 0,500 sedangkan besarnya pengaruh tidak langsung harus dihitung dengan koefisien tidak langsung yaitu: $(0,522) \times(0,067)=0,035$ dan pengaruh total yang diperoleh yaitu $0,432+0,035=0,467$. Berdasarkan hasil tersebut memliki pengaruh langsung sebesar 0,500 lebih besar dari 0,015 menunjukkan bahwa secara langsung perilaku keuangan berpengaruh terhadap literasi keuangan melalui keputusan berinvestasi

Pengujian hipotesis mediasi dapat dilakukan dengan prosedur uji sobel (sobel test) sebagai berikut:

a) Pengaruh mediasi pendapatan terhadap literasi keuangan melalui keputusan berinvestasi

$$
\begin{aligned}
\text { Sp2sp3 } & =\sqrt{(-0,067)^{2}(0,145)^{2}+(0,405)^{2}(0,028)^{2}+(0,145)^{2}(0,028)^{2}} \\
& =\sqrt{(0,0000943812)+(0,0001285956)+(0,000164837)} \\
& =\sqrt{0,0003878128} \\
& =0,019693
\end{aligned}
$$

Berdasarkan hasil Sp2p3 ini dapat digunakan untuk menghitung $\mathrm{t}$ statistik pengaruh mediasi sebagai berikut:

$t=\frac{p 2 p 3}{s p 2 p 3}=\frac{0,027}{0,019693}=1,3710$

Berdasarkan perhitungan diatas dapat diperoleh nilai t-hitung sebesar 1,3719 < t-tabel 1,969 dan koefisien mediasi 0,027, maka dapat disimpulkan bahwa keputusan berinvestasi (M) tidak dapat memediasi pengaruh pendapatan (X1) terhadap literasi keuangan (Y).

b) Pengaruh mediasi perilaku keuangan terhadap literasi keuangan melalui keputusan investasi

$$
\begin{aligned}
\text { Sp2sp3 } & =\sqrt{(-0,067)^{2}(0,083)^{2}+(0,522)^{2}(0,028)^{2}+(0,083)^{2}(0,028)^{2}} \\
& =\sqrt{(0,00003092)+(0,00021363)+(0,000005401)} \\
& =\sqrt{0,000249951} \\
& =0,015809
\end{aligned}
$$

Berdasarkan hasil Sp2p3 ini dapat digunakan untuk menghitung t statistik pengaruh mediasi sebagai berikut:

$$
t=\frac{p 2 p 3}{s p 2 p 3}=\frac{0,035}{0,015809}=2,2139
$$

Berdasarkan perhitungan diatas dapat diperoleh nilai t-hitung sebesar 2,2139 $\geq$ t-tabel 1,969 dan koefisien mediasi 0,035, maka dapat disimpulkan bahwa keputusan berinvestasi (M) dapat memediasi pengaruh perilaku keuangan (X2) terhadap literasi keuangan (Y).

\section{Pembahasan}

\section{Pendapatan Berpengaruh Signifikan Terhadap Literasi Keuangan}

Berdasarkan uji statistik diatas menunjukkan bahwa variabel pendapatan berpengaruh signifikan terhadap literasi keuangan. Penelitian ini sesuai dengan penelitian Suryanto dan Rasmini (2018) menunjukkan adanya pengaruh positif literasi keuangan dimensi tabungan dan hutang sejalan dengan peningkatan pendapatan usaha. Pada penelitian ini pendapatan usaha diukur 
melalui pendapatan rata-rata per bulan dalam satuan jutaan rupiah. Pelaku UMKM yang memiliki pendapatan usaha lebih tinggi akan cenderung memiliki literasi keuangan yang lebih tinggi. Orang yang memiliki tingkat pendapatan usaha lebih tinggi akan cenderung memiliki kemampuan untuk merencakan dan mengontrol keuangannya dengan baik. dikarenakan dengan semakin tingginya pendapatan usaha, akan semakin banyak aset yang harus dikelola oleh pelaku UMKM. Semakin tinggi pendapatan seseorang, maka orang tersebut akan berusaha mencari informasi dan pemahaman untuk memanfaatkan uang yang dimilikinya. Pendapatan yang lebih tinggi menunjukkan kesempatan yang lebih besar kepada seseorang untuk lebih bertanggung jawab terkait dengan ketersediaan dana yang dimilikinya. Selanjutnya penelitian ini juga sesuai dengan penelitian Yusnita dan Abdi (2018) menunjukkan bahwa variabel yang mempengaruhi tingkat literasi keuangan adalah variabel tingkat pendapatan dan selain variabel tersebut yang terdiri dari tingkat pendidikan, lama usaha dan usia tidak berpengaruh terhadap tingkat literasi keuangan bagi para pelaku usaha. Penelitian ini juga sesuai dengan penelitian Suryani dan Ramadhan (2017) menunjukkan bahwa variabel yang mempengaruhi tingkat literasi keuangan pelaku UMKM adalah perbedaan pendidikan dan pendapatan. Dan berbeda dengan penelitian Amaliyah dan Witiastuti (2015) menyatakan bahwa tingkat pendapatan tidak berpengaruh terhadap tingkat literasi keuangan pemilik UMKM kota Tegal.

\section{Perilaku Keuangan Berpengaruh Signifikan Terhadap Literasi Keuangan}

Berdasarkan hasil uji statistik bahwa perilaku keuangan berpengaruh postif dan signifikan terhadap literasi keuangan. Penelitian ini sejalan dengan penelitian Susanti dkk (2017) menunjukkan bahwa literasi keuangan berpengaruh positif dan signifikan terhadap perilaku keuangan UMKM. Hasil penelitian ini menunjukkan bahwa literasi keuangan berpengaruh positif terhadap perilaku keuangan UMKM dan juga mendukung penelitian Robb dan Woodyard (2011) yang menunjukkan seseorang yang perilaku keuangannya lebih percaya diri dalam hal pengetahuan keuangan, keadaan keuangan, berpengaruh terhadap perilaku keuangan yang lebih baik. Penelitian Danes dan Haberman (2007) dalam Aminatuzzahra (2014) menunjukkan bahwa perilaku keuangan yakin akan kondisi keuangan diri dapat mempengaruhi pengelolaan keuangan masa depan sehingga meningkatkan keyakinan diri dalam pengambilan keputusan.

\section{Keputusan Berinvestasi Tidak Dapat Memediasi Pengaruh Pendapatan Terhadap Literasi Keuangan}

Berdasarkan analisis jalur dalam uji sobel bahwa keputusan berinvestasi tidak dapat memediasi pendapatan terhadap literasi keuangan. Semakin besar pendapatan usaha, pelaku usaha akan memiliki cadangan dana yang lebih besar. Apabila tidak digunakan untuk pengembangan usaha utama, dana tersebut dapat dimanfaatkan untuk mendapat penghasilan tambahan, salah satunya melalui penggunaan produk investasi. Maraknya investasi bodong mengharuskan pelaku usaha yang memiliki minat untuk berinvestasi untuk mencari informasi mengenai investasi agar tidak menjadi korban penipuan. Adanya pencarian informasi agar investasi yang dipilih tepat dan sesuai akan meningkatkan literasi keuangan dimensi investasi pada pelaku usaha. Hasil penelitian ini sesuai dengan penelitian Putri dan Hamidi (2019) menunjukkan bahwa faktor demografi tidak memiliki pengaruh yang signifikan terhadap pengambilan keputusan investasi. Temuan penelitian ini menunjukkan bahwa kecuali pendidikan, variabel lain seperti jenis kelamin, usia, pendidikan, pendapatan, dan pengalaman tidak berdampak pada keputusan investasi. Selanjutnya penelitian dari Sari (2017) dengan judul Pengaruh Literasi Keuangan, Pendapatan dan Pendidikan terhadap Keputusan Investasi Keluarga Etnis di Surabaya juga mengatakan variabel pendapatan dan 
pendidikan tidak berpengaruh positif signifikan terhadap keputusan investasi. Hasil dari penelitian ini membuktikan bahwa diantara variabel kategori pendapatan tidak ada perbedaan yang signifikan pada pengambilan keputusan investasi. Menurut penelitian Putri (2017) menunjukkan bahwa Tinggi rendahnya tingkat pendapatan tidak mendorong semakin baik atau buruknya perilaku keuangan pelaku UKM meskipun didukung dengan literasi keuangan. Pendapatanyang besar jika tidak diiringi dengan pengetahuan yang cukup tentang pengelolaan keuangan pun akan membuat para pelaku UKM kewalahan karena tidak hanya teori yang dipelajari akan tetapi cara pengaplikasiannya pun perlu dipahami. Selanjutnya penelitian ini berbeda dengan penelitian Bushan (2014) menunjukkan bahwa tingkat literasi keuangan individu dapat mempengaruhi langsung keputusan berinvestasi individu terhadap pendapatan individu.

\section{Keputusan Berinvestasi Dapat Memediasi Pengaruh Perilaku Keuangan Berpengaruh Signifikan Terhadap Literasi Keuangan}

Berdasarkan hasil analisis jalur dalam uji sobel bahwa keputusan berinvestasi dapat memediasi perilaku keuangan terhadap literasi keuangan. Hal ini mendukung hasil penelitian yang dilakukan oleh Amituzzahra (2014) mengatakan variabel perilaku keuangan dalam pengambilan keputusan investasi individu yang lain dan belum dimasukkan sebagai variabel indipenden yang mempengaruhi perilaku keuangan. Zebua (2001) dalam Putri dan Rahyuda (2017) menyatakan bahwa semakin banyak seseorang memiliki uang, maka semakin meningkat pula keinginannya untuk berbelanja. Hal yang sama pada penelitian Rita dan Kusumawati (2010) menyatakan bahwa semakin tinggi pendapatan yang dimiliki seseorang, semakin besar keinginan seseorang untuk membeli apa yang diinginkan melebihi apa yang dibutuhkan, seseorang yang seperti ini kurang paham dengan manfaat menabung atau berinvestasi untuk masa depan. Selanjutnya menurut Rizwan et., al (2018) menunjukkan bahwa literasi keuangan memiliki dampak positif pada pengambilan keputusan investasi. Literasi keuangan memiliki korelasi positif dengan perilaku keuangan (Financial Behavior). Dwiastanti (2015:8) dalam Sari (2019) menyatakan bahwa jika seseorang memiliki literasi keuangan yang baik, maka dia akan lebih pintar dalam mengelola keuangan untuk mencapai kesejahteraan. Perilaku keuangan seseorang dapat ditunjukkan dengan bagaimana orang memperlakukan, mengelola, dan menggunakan sumber daya keuangan yang tersedia baginya. Munculnya financial behaviour, merupakan dampak dari besarnya hasrat seseorang untuk memenuhi kebutuhan hidupnya sesuai dengan keputusan investasi yang diperoleh.

\section{PENUTUP}

Berdasarkan hasil penelitian diatas dapat disimpulkan bahwa pendapatan mempengaruhi literasi keuangan pada pelaku UMKM kota Tangerang Selatan. Hasil ini menunjukkan bahwa jika semakin tinggi pendapatan usaha, maka literasi keuangannya juga akan mengalami peningkatan. Kemudian perilaku keuangan berpengaruh terhadap literasi keuangan. Semakin tinggi literasi keuangan akan mendorong semakin baiknya perilaku keuangan. Berbanding terbalik, jika literasi keuangan rendah maka akan berimplikasi terhadap semakin tidak baiknya perilaku keuangan. Berdasarkan dari hasil uji sobel bahwa keputusan invesatasi tidak dapat memediasi pengaruh pendapatan terhadap literasi keuangan. Semakin tingginya pendapatan tidak akan mendorong semakin tingginya literasi keuangan. Jumlah pendapatan seseorang ternyata tidak memiliki pengaruh langsung dalam mengukur literasi keuangannya melainkan tergantung kebijaksanaan 
orang dalam mengelola pengetahuannya terkait dalam pengambilan keputusan investasi nya. Dan untuk hipotesis keempat menunjukkan bahwa keputusan investasi dapat memediasi pengaruh signifikan perilaku keuangan terhadap literasi keuangan. Jika seseorang memiliki literasi keuangan yang baik maka akan mempengaruhi perilaku seseorang secara langsung dalam mengambil keputusan berinvestasi.

Saran dalam penelitian ini adalah bagi pelaku UMKM perlu menyadari bahwa pentingnya financial literacy dalam pengelolaan dana karena faktor ini merupakan faktor utama di dalam melakukan sebuah investasi dimana akan bermanfaat ketika di masa mendatang. Diharapkan kepada lembaga jasa keuangan agar lebih melakukan sosioalisasi tentang financial literacy kepada masyarakat khususnya pelaku UMKM. Bagi pihak pemegang kebijakan, yaitu Dinas Koperasi dan UKM Kota Tangerang Selatan, bahwa UMKM merupakan salah satu sektor vital bagi perekonomian sehingga dengan adanya hasil penelitian ini diharapkan Dinas Koperasi dan UKM Kota Tangerang Selatan lebih aktif dalam melakukan sosialisasi terkait literasi keuangan dalam pemanfaatan produk dan layanan jasa keuangan. Kemudian melakukan kegiatan pelatihan dan workshop terkait literasi keuangan akan sangat membantu peningkatan pengetahuan dan kemampuan pengelolaan keuangan pada pelaku UMKM. Dan Pemerintah hendaknya melakukan kerjasama dengan OJK untuk memberikan sosialisasi terkait literasi keuangan dan OJK lebih memperluas jangkauan dalam pemberian sosialisasi dan edukasi literasi keuangan kepada UMKM. Bagi peneliti selanjutnya disarankan untuk menggunakan metode pengambilan sampel yang berbeda sebab metode sampling random masih kurang cukup mempresentasikan literasi keuangan pelaku UMKM karena literasi keuangan yang dimiliki oleh pelaku UMKM yang baru memulai usaha dapat berbeda dengan literasi keuangan yang dimiliki oleh pelaku UMKM yang sudah cukup berpengalaman dalam menjalankan usahanya selain itu peneliti selanjutnya dapat memperluas area penelitian sebab penelitian ini masih terbatas pada daerah tertentu yang ada di setiap kecamatan sehingga akan lebih baik jika pada penelitian selanjutnya tersebar secara merata di setiap daerah yang ada di tujuh kecamatan di Kota Tangerang Selatan. 
PENGARUH PENDAPATAN DAN PERILAKU KEUANGAN TERHADAP LITERASI KEUANGAN MELALUI KEPUTUSAN BERINVESTASI SEBAGAI VARIABEL INTERVENING

Baiq Fitri Arianti

\section{DAFTAR PUSTAKA}

Aminatuzzahra (2014). Persepsi Pengaruh Pengetahuan Keuangan, Sikap Keuangan, Sosial Demografi Terhadap Perilaku Keuangan Dalam Pengambilan Keputusan Investasi Individu (Studi Kasus Pada Mahasiswa Magister Manajemen Universitas Diponegoro). Jurnal Bisnis STRATEGI, 23 (2) : 70 - 96.

Amaliyah, Riski, dan Witiastuti, R.S. (2015). Analisis Faktor Yang Mempengaruhi Tingkat Literasi Keuangan Di Kalangan UMKM Di Kota Tegal. Management Analysis Journal, 4 (3) : 252 - 257, ISSN 2252-6552.

Akdon, dan Riduwan. (2013). Analisis Statistika. Alfabeta. Bandung.

Anggraeni, Birawani D. (2016). Pengaruh Tingkat Literasi Keuangan Pemilik Usaha Terhadap Pengeloaan Keuangan. Studi Kasus : Umkm Depok. Jurnal Vokasi Indonesia, 4 (1) : 43 - 50

ANZ Banking Group. (2015). ANZ Survey of Adult Financial literacy in Australia. 182 <http://www.anz.com/Documents/AU/Aboutanz/AN_5654_Adult_Fin_Lit_Report_08_Web_ Report_full.pdf>

Arianti, B.F. (2018). The Influence of Financial literacy, Financial Behavior and Income on Investment Decision. Economic Accounting Journal, 1 (1) : 1- 10

Bhushan, Puneet, dan Yajulu Medury. (2013). Financial literacy and Its Determinants. Journal of Business Management \& Social Sciences Research (JBM\&SSR). 3 (5):82 - 87

Christanti, Natalia, dan Linda Ariany Mahastanti. (2011). Faktor-Faktor Yang Dipertimbangkan Investor Dalam Melakukan Investasi. Jurnal Manajemen Teori Dan Terapan, 4 (3) : 37-51

Deasy Lestary Kusnandar dan Dian K. (2018). Literasi Keuangan Dan Gaya Hidup Ibu Rumah Tangga Dalam Membentuk Perilaku Keuangan Keluarga Di Kota Tasikmalaya. Seminar Nasional Dan Call for Paper Sustainable Competitive Advantage, Seminar Nasional dan Call for Paper Sustainable Competitive Advantage (SCA) 8, 1-13

Dewi, Mertha, Iga, and Ida Bagus Anom Purbawangsa. (2018). Pengaruh Literasi Keuangan, Pendapatan Serta Masa Bekerja Terhadap Perilaku Keputusan Investasi. E-Jurnal Ekonomi Dan Bisnis Universitas Udayana, 7. (7) : 1867-1894, ISSN : 2337-3067

Ghozali, Imam. (2011). Aplikasi Analisis Multivariate Dengan Program SPSS. Badan Penerbit Universitas Diponegoro. Semarang.

Humaira, Iklima, dan Endra Murti S. (2018). Pengaruh Pengetahuan Keuangan, Sikap Keuangan, Dan Kepribadian Terhadap Perilaku Manajemen Keuangan Pada Pelaku Umkm Sentra Kerajinan Batik Kabupaten Bantul. Jurnal Nominal, 7 (1) : 96 - 110

Khalid, Rizwan, Muhammad Usman Javed, and Khurram S. (2018). Impact of Behavioral Biases on Investment Decision Making with Moderating Role of Financial literacy Literature Review Investment Decision. Jinnah Business Review, 6 (2) : 34-41

Kholilah, Naila Al, and Rr. Iramani. (2013). Studi Financial Management Behavior Pada Masyarakat Surabaya. Journal of Business and Banking, 3 (1) : 69 - 80

Lumintang, Fatmawati. (2013). Analisis Pendapatan Petani Padi Di Desa Teep Kecamatan Langowan Timur. Jurnal Riset Ekonomi, Manajemen, Bisnis Dan Akuntansi, 1 (3) : 991-998

Lusardi, Annamaria, dan Olivia S. M. (2012). Financial literacy Around the World : An Overview. SSRN Electronic Journal. https://doi.org/10.2139/ssrn.1810551>

Mahdzan, Nurul Shahnaz, and Saleh T. (2013). The Impact of Financial literacy on Individual Saving: An Exploratory Study in the Malaysian Context. Transformations in Business and Economics, 12 (1) : 41-55 
Manurung, Adler Haymans. (2012). Teori Perilaku Keuangan (Behaviour Finance). Economis Of Management. 41(4) : 1-13

Moleong, L. J. (2010). Metodologi Penelitian Kualitatif. Remaja Rosdakarya. Bandung.

OJK. (2017). Strategi Nasional Literasi Keuangan Indonesia (Revisit 2017). Otoritas Jasa Keuangan. 1-99. Diakses Tanggal 23 Januari 2020.

Putri, Anendy, Ramadhani and Isbanah, Y. (2020). Faktor - Faktor Yang Mempengaruhi Keputusan Investasi Pada Investor Saham Di Surabaya. Jurnal Ilmu Manajemen. 8 (1) : 197 - 209.

Putri, Riantira Purnama. (2017). Pengaruh Faktor Demografi Dan Motivasi Terhadap Perilaku Keuangan Pelaku UKM Di Kota Makassar Dengan Literasi Keuangan Sebagai Variabel Intervening. 1-130. Skripsi. UIN ALAUDDIN MAKASSAR. Diakses Tanggal 23 Januari 2020.

Putri, Wilantika Waskito, and Masyhuri Hamidi. (2019). Pengaruh Literasi Keuangan, Efikasi Keuangan, Dan Faktor Demografi Terhadap Pengambilan Keputusan Investasi (Studi Kasus Pada Mahasiswa Magister Manajemen. JIM.Unsyiah.ac.id. 4(1):398-412

Rahmayanti, Wilda, Hanifah Sri Nuryani dan Abdul Salam. (2019). Pengaruh Sikap Keuangan Dan Perilaku keuangan Terhadap Literasi Keuangan (Studi Kasus Pada Ibu Rumah Tangga Di Desa Lito Kecamatan Moyo Hulu). Jurnal Manajemen Dan Bisnis. 2 (1)

Rasuma Putri, Ni Made Dwiyana, and Henny Rahyuda (2017). Pengaruh Tingkat Financial literacy Dan Faktor Sosiodemografi Terhadap Perilaku Keputusan Investasi Individu. E-Jurnal Ekonomi Dan Bisnis Universitas Udayan, 6 (9) : 3407-3434

Remund, David L. (2010). Financial literacy Explicated: The Case for a Clearer Definition in an Increasingly Complex Economy. Journal of Consumer Affairs, 44 (2) : 276-95

Rita, Maria, and Ratna Kusumawati (2011). Pengaruh Variabel Sosio Demografi Dan Karakteristik Finansial Terhadap Sikap, Norma Subyektif Dan Kontrol Perilaku Menggunakan Kartu Kredit (Studi Pada Pegawai Di UKSW Salatiga). Jurnal Manajemen Dan Keuangan, 9 (2) : 109-28

Sabri, Mohamad Fazli Fazli. (2011). Pathways to financial success: Determinants of financial literacy and financial well-being among young adults. Graduate Theses and Dissertations. 11205.

Sari, Dea Rachmalita. (2017). Pengaruh Literasi Keuangan, Pendapatan, Dan Pendidikan Terhadap Keputusan Investasi Keluarga Etnis China Di Surabaya. Artikel Ilmiah. STIE Perbanas Surabaya. Diakses Tanggal 23 Januari 2020.

Sari, Dian Anita. (2015). Financial literacy Dan Perilaku Keuangan Mahasiswa. Buletin Bisnis \& Manajemen, 01 (02) : 171-89

Sari, Mitha. (2019). Analisis Tingkat Literasi Keuangan Pada UMKM Peremuan Bidang Fashion Di Unit Pasar Kencong Baru. Prosiding The 5th Seminar Nasional dan Call for Paper, The 5th SNCP 2019, ISBN : 978-602-6988-71-3 : 221-29

Suryanto, Suryanto, and Mas Rasmini. (2018). Analisis Literasi Keuangan Dan Faktor-Faktor Yang Mempengaruhinya. Jurnal Ilmu Politik Dan Komunikasi, 8 <https://doi.org/10.34010/jipsi.v8i2.1336>

Sugiyono (2013). Metode Penelitian Kualitatif, Kuantitatif dan R\&D. Alfabeta. Bandung.

Widowati, Mustika, and Winarto (2017). Literasi Keuangan Pelaku UMKM Kota Semarang. Jurnal Ilmiah Akuntansi Dan Keuangan, 3 (2) : 10-18

$\mathrm{Xu}$, Lisa, Zia, Bilal. (2012). Financial literacy around the World An Overview of the Evidence with Practical Suggestions for the Way Forward, 'The World Bank Development Research 
PENGARUH PENDAPATAN DAN PERILAKU KEUANGAN TERHADAP LITERASI KEUANGAN MELALUI

KEPUTUSAN BERINVESTASI SEBAGAI VARIABEL INTERVENING

Baiq Fitri Arianti

Group Finance and Private Sector Development Team. Diakses Tanggal 23 Januari 2020.

Yusnita, Ria, Raja, and Abdi, Muhammad. (2018). Pengaruh Faktor Demografi Terhadap Literasi

Keuangan. Journal of Economic, Business and Accounting (COSTING), 2(1), e-ISSN : 25975234 https://doi.org/10.31539/costing.v2i1.388 